\title{
Identification of differentially expressed microRNAs and the possible role of miRNA-126* in Sprague-Dawley rats during fetal lung development
}

\author{
YANG YANG $^{1}$, XIAO-DAN PU ${ }^{1}$, KAN QING $^{1}$, XI-RONG GUO ${ }^{2}$, XIAO-YU ZHOU ${ }^{1}$ and XIAO-GUANG ZHOU ${ }^{1}$ \\ ${ }^{1}$ Department of Neonates, Nanjing Children's Hospital of Nanjing Medical University, Nanjing, Jiangsu 210008; \\ ${ }^{2}$ Department of Pediatrics, Nanjing Maternal and Child Health Hospital of Nanjing Medical University, \\ Nanjing, Jiangsu 210004, P.R. China
}

Received June 3, 2012; Accepted October 5, 2012

DOI: $10.3892 / \mathrm{mmr} .2012 .1130$

\begin{abstract}
The aim of this study was to conduct a search for microRNAs (miRNAs) that are significant in fetal lung development to lay a foundation for further studies in the relevant fields. In this study, histological observation was performed in rats by hematoxylin and eosin (H\&E) staining at three time points of fetal lung development [Embryo 21 (E21), E19 and E16, and designated as groups S1, S2 and S3, respectively]. An expression profile for fetal lung development was determined using the latest microarray technology. Furthermore, certain differentially expressed miRNAs were selected for further study by real-time PCR. In total, 202 differentially expressed miRNAs were identified. Among them, miRNA-126* was selected for further study and validated by real-time PCR due to its higher expression levels in the microarrays. The results revealed that the relative expression of miRNA-126* differentially increased as embyronic development increased $(\mathrm{P}<0.05)$, which was consistent with the microarray results. In conclusion, we hypothesize that these newly identified miRNAs (including miRNA-126*) may be important in the physiological mechanisms during fetal lung development. These results may aid future studies of neonatal lung development.
\end{abstract}

\section{Introduction}

As one class of newly identified regulatory molecules, miRNAs are important in numerous critical cell processes, including cell proliferation, differentiation and apoptosis (1-3). It has been found that $\sim 30 \%$ of the mammalian genome is

Correspondence to: Professor Xiao-Yu Zhou or Professor Xiao-Guang Zhou, Department of Neonates, Nanjing Children's Hospital of Nanjing Medical University, 72 Guangzhou Road, Nanjing, Jiangsu 210008, P.R. China

E-mail: yy860507@126.com

E-mail: gzzhouxg@163.com

Key words: lung development, microRNA, rats, miRNA-126* regulated by these short endogenous RNAs. As for their functions, it is widely recognized that microRNAs (miRNAs) are able to integrate with specific target mRNAs, forming close complementary structures and resulting in either mRNA degradation or inhibition of protein translation (4). In addition, miRNAs alter gene expression mainly through their effects on the methylation of genes or by the targeting of transcription factors significant to cell physiology $(5,6)$.

Over the last several years, studies have demonstrated that these tiny regulators are able to tune organ development (7). However, few of those involved the physiological or pathological mechanisms of the lungs, particularly in mammalian fetal lung development, have been identified. The lung has a specific stable miRNA expression profile, which is conserved across mammalian species $(8,9)$. Therefore, in theory it is comparable among different species. However, over the past several years, the number of expression profile studies on fetal development in mammals has been relatively small and these studies have been mostly confined to a few miRNAs, including the Let-7 family $(10,11)$ and the miRNA-17-92 cluster $(12,13)$. However, with the improvement of chip technology and the deepening understanding of the developmental mechanism, we are able to identify more of the significant miRNAs involved in fetal lung development using the latest microarrays. Therefore, in the present study, we used the miRCURY LNA ${ }^{\mathrm{TM}}$ microRNA Array (v.16.0) (containing $>1891$ probes) to determine expression profiles for fetal lung development at three key time points to identify new miRNAs. We then selected certain miRNAs for further study in order to attempt to clarify the possible mechanism involved.

\section{Materials and methods}

Rats. Healthy adult Sprague-Dawley rats (12 female and 12 male) were maintained in a specific-pathogen-free animal facility at the Animal Center of Nanjing Medical University. In this study, 3 time points (gestational days 16, 19 and 21) representing 3 stages of fetal lung development were selected. The 3 time points were designated as groups S1 (E21), S2 (E19) and S3 (E16). For each group, 4 pregnant rats were selected according to the random contrast rule. 
The pregnant rats were sacrificed with $\mathrm{CO}_{2}$ and whole fetal lungs were immediately isolated from the fetuses. The superfluous extraneous tissues were then removed as thoroughly as possible. The procedures in this study followed the protocols approved by the Nanjing Medical University Animal Care and Use Committee.

Following isolation, a randomly selected fetal lung was retained for histological observation. Subsequently, the total RNA of the remaining lungs was isolated using TRIzol (Invitrogen Life Technologies, Carlsbad, CA, USA) and the miRNeasy mini kit (Qiagen, Hilden, Germany) according to the manufacturer's instructions. RNA quality and quantity were measured using a NanoDrop spectrophotometer (ND-1000, Nanodrop Technologies, Wilmington, DE, USA) and RNA integrity was evaluated by gel electrophoresis.

Histology. The lung tissues of the 3 groups were fixed with $4 \%$ paraformaldehyde solution, embedded in paraffin and cut into $4 \mu \mathrm{m}$ continuous sections. The sections were stained with hematoxylin and eosin (H\&E) for subsequent morphological observation. H\&E sections were then viewed by optical microscopy at x40 magnification to observe the structural changes of the fetal lungs in the 3 groups (S1, S2 and S3).

miRNA microarray. Following the isolation of the RNA from the fetal lungs, the miRCURY $\mathrm{Hy} 3^{\mathrm{TM}} / \mathrm{Hy} 5^{\mathrm{TM}}$ Power labeling kit (Exiqon, Vedbaek, Denmark) was used according to the manufacturer's guidelines for miRNA labeling. Each sample $(1 \mu \mathrm{g})$ was $3^{\prime}$-end-labeled with a $\mathrm{Hy} 3^{\mathrm{TM}}$ fluorescent label using T4 RNA ligase by the following steps. RNA in $2.0 \mu \mathrm{l}$ water was combined with $1.0 \mu \mathrm{l} \mathrm{CIP}$ buffer and CIP (Exiqon). The mixture was incubated for $30 \mathrm{~min}$ at $37^{\circ} \mathrm{C}$ and then the reaction was terminated by incubation at $95^{\circ} \mathrm{C}$ for $5 \mathrm{~min}$. Then $3.0 \mu \mathrm{l}$ labeling buffer, $1.5 \mu \mathrm{l}$ fluorescent label (Hy3 $\left.3^{\mathrm{TM}}\right), 2.0 \mu \mathrm{l}$ DMSO and $2.0 \mu \mathrm{l}$ labeling enzyme were added to the mixture. The labeling reaction was incubated for $1 \mathrm{~h}$ at $16^{\circ} \mathrm{C}$ and the reaction was terminated by incubation at $65^{\circ} \mathrm{C}$ for $15 \mathrm{~min}$.

The Hy $3^{\mathrm{TM}}$-labeled miRNA samples were hybridized using the miRCURY LNA ${ }^{\mathrm{TM}}$ microRNA array system (v.16.0) (Exiqon) according to the array manual. The total $25 \mu \mathrm{l}$ mixture of $\mathrm{Hy} 3^{\mathrm{TM}}$-labeled samples in $25 \mu$ l hybridization buffer was denatured for $2 \mathrm{~min}$ at $95^{\circ} \mathrm{C}$, incubated on ice for $2 \mathrm{~min}$ and then hybridized to the microarray for $16-20 \mathrm{~h}$ at $56^{\circ} \mathrm{C}$ in the 12-Bay hybridization system (Nimblegen Systems, Inc., Madison, WI, USA), which provides an active mixing action and constant incubation temperature to improve hybridization uniformity and enhance the signals. Following hybridization, the slides were washed several times using a wash buffer kit (Exiqon) and dried by centrifugation for $5 \mathrm{~min}$ at $400 \mathrm{rpm}$. The slides were scanned using the Axon GenePix 4000B microarray scanner (Axon Instruments, Foster City, CA, USA).

The scanned images were imported into GenePix Pro 6.0 software (Axon Instruments) for grid alignment and data extraction. Replicated miRNAs were averaged and miRNAs that had intensities $>50$ in all samples were selected for calculation of the normalization factor. The expressed data were normalized by median normalization. Following normalization, the differentially expressed miRNAs were identified through fold-change filtering (fold change $\geq 1.0$ ).

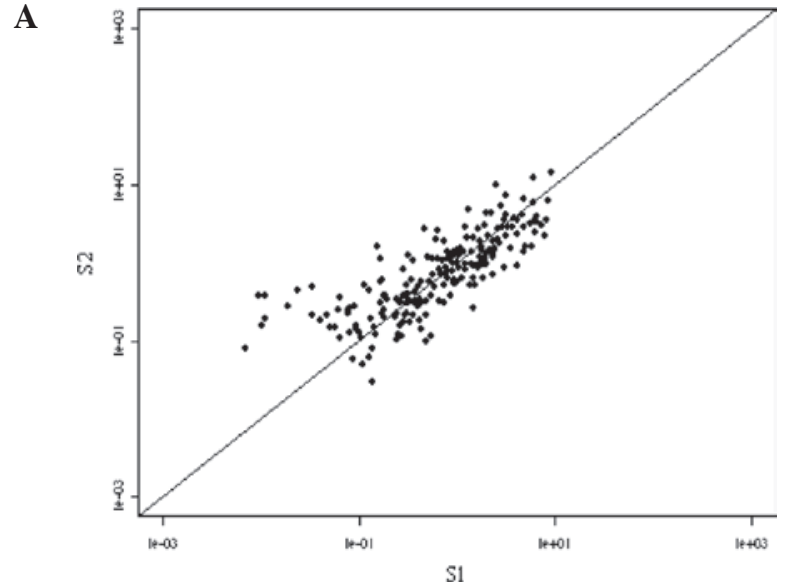

B

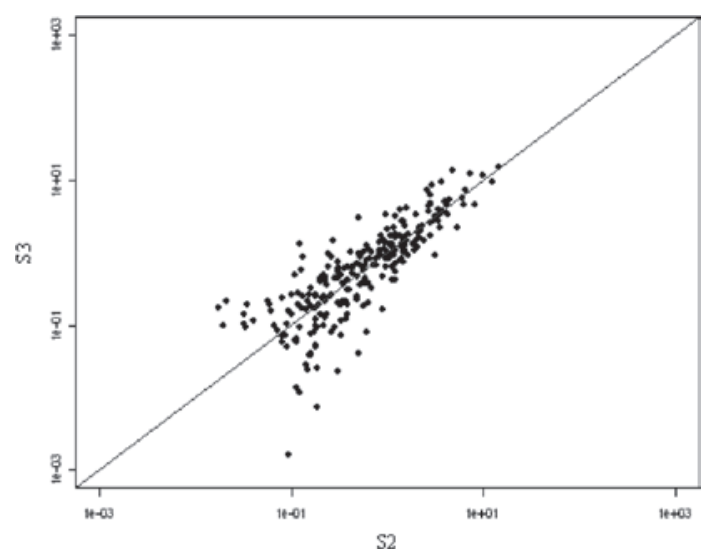

C

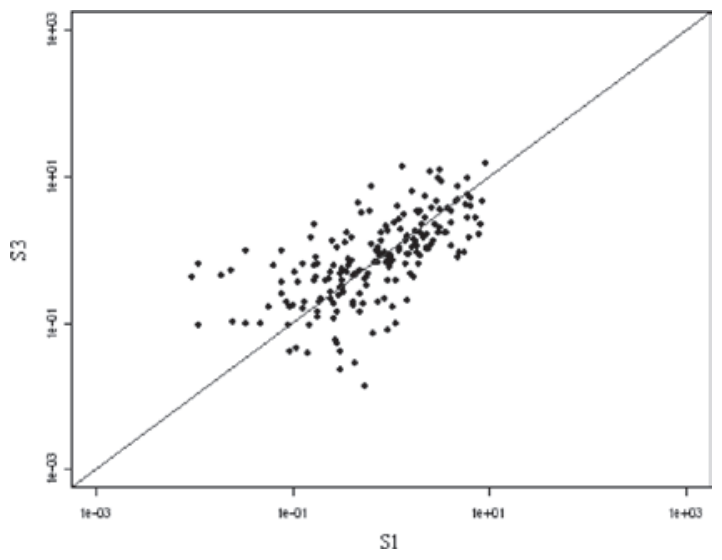

Figure 1. Scatter-plots were performed to assess the variation (or reproducibility) among the chips of the 3 groups (S1, S2 and S3). Axes of the scatter-plot are the normalized signal values of the samples (ratio scale).

Scatter-plots and correlation coefficient matrices which were visualizations used to assess the variation (or reproducibility) between chips were prepared (Fig. 1 and Table I). The axes of the scatter-plot are the normalized signal values of the samples (ratio scale).

Quantitative real-time PCR. Total RNA was isolated from fetal lungs using the TRIzol reagent. Single-strand cDNA was synthesized using a reverse transcription mixture that contained $1 \mu \mathrm{g}$ total RNA, $0.3 \mu 1$ rno-miRNA reverse primer $(1 \mu \mathrm{M})$ (Table II), $0.1 \mu 1 \mathrm{MMLV}$ revertase $(200 \mathrm{U} /$ $\mu \mathrm{l}$; Epicentre, Madison, WI, USA), $2 \mu \mathrm{l}$ 10X RT buffer, $2 \mu \mathrm{l}$ 
Table I. Correlation coefficient matrix among 3 microarrays (groups S1, S2 and S3).

\begin{tabular}{lccc}
\hline Group & S1 & S2 & S3 \\
\hline S1 & 1.0000 & 0.7084 & 0.5440 \\
S2 & 0.7084 & 1.0000 & 0.8600 \\
S3 & 0.5440 & 0.8600 & 1.0000 \\
\hline
\end{tabular}

Table II. RT primer sequences.

\begin{tabular}{ll}
\hline Gene & \multicolumn{1}{c}{$\begin{array}{c}\text { RT primers } \\
\left(5^{\prime}-3^{\prime}\right)\end{array}$} \\
\hline U6 & CGCTTCACGAATTTGCGTGTCAT \\
rno-miR-126* & GTCGTATCCAGTGCGTGTCGTGGA \\
& GTCGGCAATTGCACTGGATACGAC \\
& CGCGTA
\end{tabular}

dNTP mix (2.5 mM each) and $0.3 \mu \mathrm{l}$ ribonuclease inhibitor (40 U/ $\mu \mathrm{l})$ in a $20 \mu \mathrm{l}$ total volume. The reaction was performed at $16^{\circ} \mathrm{C}$ for $30 \mathrm{~min}$ and at $42^{\circ} \mathrm{C}$ for $40 \mathrm{~min}$, followed by heat inactivation at $85^{\circ} \mathrm{C}$ for $5 \mathrm{~min}$. For real-time PCR, $1 \mu \mathrm{l} \mathrm{cDNA}$ was added to $24 \mu \mathrm{l}$ master mix containing $2.5 \mu \mathrm{l} \mathrm{dNTP}$ (2.5 mM each), $2.5 \mu \mathrm{l}$ 10X PCR buffer (Promega, Madison, WI, USA), 1 unit Taq polymerase (Promega), final concentration 0.25X SYBR-Green I (Invitrogen) and $2 \mu \mathrm{l}$ reverse and forward primers. cDNA was then amplified for 35 cycles using the Applied Rotor-Gene 3000 (Corbett Research, Sydney, Australia) real-time PCR system. The primer sequences used are listed in Table III. RT and PCR for U6 snRNA were performed in each plate as an endogenous control. The amount of PCR product was calculated from the threshold cycle $(\mathrm{Ct})$. In addition, the comparative $\mathrm{C}_{\mathrm{T}}$ method was used, and the relative amount of miRNA to U6 snRNA was calculated with the equation $2^{-(\mathrm{Ct} \text { microRNA - Ct U6) }}$.

Statistical analysis. Data were analyzed using the SPSS 13.0 statistical package and EXCEL 2003. The real-time PCR data were evaluated by one-way ANOVA. $\mathrm{P}<0.05$ was considered to indicate a statistically significant result.
Table III. Primers for real-time RT-PCR.

\begin{tabular}{llc}
\hline Gene & \multicolumn{1}{c}{$\begin{array}{c}\text { Primers } \\
\left(5^{\prime}-3^{\prime}\right)\end{array}$} & $\mathrm{T}\left({ }^{\circ} \mathrm{C}\right)$ \\
\hline U6 & F: GCTTCGGCAGCAC & \\
& ATATACTAAAAT & \\
& R: CGCTTCACGAAT & 60 \\
& TTGCGTGTCAT & \\
rno-miR-126* & GSP: GGGCATTAT & \\
& TACTTTTGG & 60 \\
& R: TGCGTGTC & \\
& GTGGAGTC & \\
\hline
\end{tabular}

\section{Results}

Histology. In group S3 (E16), the epithelial cells had differentiated into original acinar-like structures. The structure of the interstitial tissue was extremely dense (Fig. 2A), while in group S2 (E19), the acinus cavities had expanded rapidly. The interstitium was arranged in cords and appeared to be thinner than in E16 (Fig. 2B); in group S1 (E21), more mature alveolars emerged and were arranged around the bronchioles. The interstitium was sparser than in the previous groups (Fig. 2C).

miRNA expression profile. The 6th generation miRCURY LNA $^{\mathrm{TM}}$ microRNA array (v.16.0) that we used covers all mouse, rat, human and virus genomes. As a result, 202 differentially expressed miRNAs from the 3 groups (S1, S2 and S3) passed the fold-change filtering (fold change $\geq 1.0$ ), including 4 different types of expression patterns (S2/S3 †or $\downarrow$ and S1/S2 †or $\downarrow$ ) (Table IV).

In addition, in view of their classic status in lung development, we also selected some representative members of the rno-Let-7 family and rno-miRNA-17-92 cluster from the differentially expressed miRNAs (Table IV) to generate line charts reflecting their expression trends during fetal lung development (Fig. 3). Compared with these intensely investigated miRNAs, certain other miRNAs, including miRNA-126* and miRNA-126, have been scarcely reported on and studied in lung development. However, both have been revealed
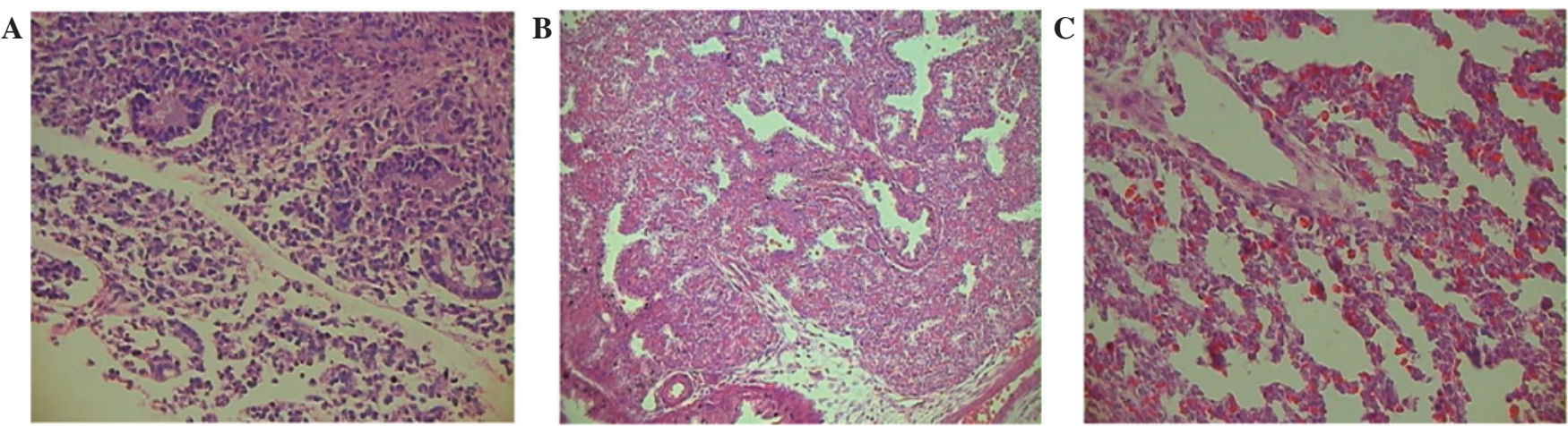

Figure 2. Observation of fetal lung tissue in 3 groups: (A) S1 (E21), (B) S2 (E19) and (C) S3 (E16) under an optical microscope; magnification, x40. The tissue was stained with hematoxylin and eosin (H\&E). 
Table IV. All differentially expressed miRNAs among the 3 groups (S1, S2 and S3), including 4 expression patterns (S2/S3 †or $\downarrow$ and $\mathrm{S} 1 / \mathrm{S} 2$ †or $\downarrow)$.

\begin{tabular}{|c|c|c|c|c|c|}
\hline \multicolumn{3}{|c|}{$\mathrm{S} 3-\mathrm{S} 2 \uparrow, \mathrm{S} 2-\mathrm{S} 1 \uparrow(\mathrm{S} 2 / \mathrm{S} 3>1 \text { and } \mathrm{S} 1 / \mathrm{S} 2>1)^{\mathrm{a}}$} & \multicolumn{3}{|c|}{$\mathrm{S} 3-\mathrm{S} 2 \downarrow, \mathrm{S} 2-\mathrm{S} 1 \downarrow(\mathrm{S} 2 / \mathrm{S} 3<1 \text { and } \mathrm{S} 1 / \mathrm{S} 2<1)^{\mathrm{a}}$} \\
\hline \multirow{2}{*}{$\begin{array}{l}\text { Name } \\
\text { rno-miR-3560 }\end{array}$} & \multicolumn{2}{|c|}{ Fold changes } & \multirow{2}{*}{$\frac{\text { Name }}{\text { rno-miR-186* }}$} & \multicolumn{2}{|c|}{ Fold changes } \\
\hline & 8.4211415 & 4.888905 & & 0.980325 & 0.68844749 \\
\hline rno-miR-126* & 7.5239524 & 1.511816 & rno-miR-466c* & 0.977220 & 0.87722704 \\
\hline rno-miR-672* & 5.2601791 & 1.175347 & rno-miR-19a & 0.971818 & 0.62082771 \\
\hline rno-miR-146b & 5.0163166 & 3.094662 & rno-miR-25 & 0.963684 & 0.57179299 \\
\hline rno-miR-34c & 4.5061344 & 1.957254 & rno-miR-144 & 0.951005 & 0.64339048 \\
\hline rno-miR-653* & 3.4649380 & 1.764355 & rno-miR-329 & 0.923679 & 0.93020848 \\
\hline rno-miR-411* & 3.3178232 & 1.590243 & rno-miR-331 & 0.903534 & 0.02509753 \\
\hline rno-miR-let-7a & 3.1785206 & 2.289511 & rno-miR-19b & 0.900471 & 0.72076563 \\
\hline rno-miR-let-7d & 2.9136439 & 1.452478 & rno-miR-151* & 0.892133 & 0.39417882 \\
\hline rno-miR-26b & 1.9370148 & 1.723152 & rno-miR-451 & 0.878429 & 0.25339903 \\
\hline rno-miR-874 & 1.8857111 & 2.413461 & rno-miR-21* & 0.874866 & 0.65841255 \\
\hline rno-miR-1188-3p & 1.7935323 & 2.298813 & rno-miR-7a- $2 *$ & 0.852774 & 0.38291656 \\
\hline rno-miR-23a & 1.7799642 & 1.206440 & rno-miR-652 & 0.846386 & 0.71646338 \\
\hline rno-miR-329* & 1.7775597 & 1.262534 & rno-miR-186 & 0.822947 & 0.05419442 \\
\hline rno-miR-30d & 1.7484931 & 3.044324 & rno-miR-106b & 0.817602 & 0.50922622 \\
\hline rno-miR-138-2* & 1.7377907 & 1.740641 & rno-miR-204* & 0.797339 & 0.5891234 \\
\hline rno-miR-30b-5p & 1.7229757 & 1.254918 & rno-miR-20a & 0.790606 & 0.33531233 \\
\hline rno-miR-26a & 1.7208078 & 3.452369 & rno-miR-99a & 0.785670 & 0.28761068 \\
\hline rno-miR-let-7c & 1.6864176 & 1.272732 & rno-miR-345-5p & 0.732098 & 0.79662712 \\
\hline rno-miR-743b & 1.6569246 & 1.746423 & rno-miR-106b* & 0.721485 & 0.86241946 \\
\hline rno-miR-352 & 1.6529537 & 2.337057 & rno-miR-23b & 0.712766 & 0.97392883 \\
\hline rno-miR-539* & 1.6424152 & 2.621551 & rno-miR-674-5p & 0.695417 & 0.80928285 \\
\hline rno-miR-136 & 1.6394235 & 2.305536 & rno-miR-431 & 0.690826 & 0.29360741 \\
\hline rno-miR-138-1* & 1.4810756 & 1.463674 & rno-miR-152 & 0.682139 & 0.75124564 \\
\hline rno-miR-376a & 1.4443813 & 1.631507 & rno-miR-758* & 0.677330 & 0.72947047 \\
\hline rno-miR-664 & 1.4361529 & 1.661272 & rno-miR-344b-1-3p & 0.660900 & 0.51092973 \\
\hline rno-miR-127 & 1.4246079 & 1.449653 & rno-miR-664-1* & 0.656291 & 0.33467595 \\
\hline rno-miR-145 & 1.4116241 & 1.584110 & rno-miR-17-5p & 0.651909 & 0.71146565 \\
\hline rno-miR-207 & 1.3967711 & 1.344485 & rno-miR-183 & 0.645298 & 0.06785863 \\
\hline rno-miR-331* & 1.3332774 & 3.647136 & rno-miR-298 & 0.622817 & 0.32752771 \\
\hline rno-miR-323 & 1.3300142 & 1.247038 & rno-miR-199a-5p & 0.619426 & 0.42597925 \\
\hline rno-miR-294 & 1.2375557 & 1.770187 & rno-miR-181d & 0.618991 & 0.30448551 \\
\hline rno-miR-21 & 1.2271042 & 1.679205 & rno-miR-140* & 0.612127 & 0.17284846 \\
\hline rno-miR-32* & 1.2216227 & 1.257030 & rno-miR-218 & 0.610725 & 0.02906206 \\
\hline rno-miR-378 & 1.2187415 & 1.174652 & rno-miR-140 & 0.602168 & 0.17782928 \\
\hline rno-miR-let-7d* & 1.1706845 & 1.128949 & rno-miR-505* & 0.546060 & 0.7634096 \\
\hline rno-miR-134* & 1.1520524 & 2.038411 & rno-miR-320 & 0.535097 & 0.53630321 \\
\hline rno-miR-742 & 1.1370318 & 2.165993 & rno-miR-361 & 0.521556 & 0.06827078 \\
\hline rno-miR-465 & 1.1331676 & 1.424808 & rno-miR-483 & 0.518141 & 0.32997545 \\
\hline rno-miR-340-5p & 1.1306514 & 1.900459 & rno-miR-191 & 0.507004 & 0.14680991 \\
\hline rno-miR-34b* & 1.0914578 & 2.423233 & rno-miR-434 & 0.504917 & 0.86745761 \\
\hline rno-mir-141 & 1.0728281 & 1.002083 & rno-miR-485* & 0.498218 & 0.56491937 \\
\hline rno-mir-181b & 1.0632784 & 1.197243 & rno-miR-214 & 0.451194 & 0.59062997 \\
\hline rno-mir-27b & 1.0548732 & 1.005943 & rno-miR-185* & 0.385377 & 0.74238926 \\
\hline rno-mir-465* & 1.0445459 & 2.298723 & rno-miR-1949 & 0.381056 & 0.42356006 \\
\hline rno-mir-382 & 1.0444827 & 1.091136 & rno-miR-130a & 0.374817 & 0.84478535 \\
\hline rno-mir-503 & 1.0266687 & 1.160400 & rno-miR-93 & 0.359659 & 0.24274816 \\
\hline & & & rno-miR-130b & 0.353169 & 0.84478535 \\
\hline & & & rno-miR-125b-5p & 0.350006 & 0.27382858 \\
\hline & & & rno-miR-9* & 0.304562 & 0.78517235 \\
\hline & & & rno-miR-296 & 0.248001 & 0.31706143 \\
\hline & & & rno-miR-101b & 0.221090 & 0.94937991 \\
\hline
\end{tabular}


Table IV. Continued.

\begin{tabular}{|c|c|c|c|c|c|}
\hline \multicolumn{3}{|c|}{$\mathrm{S} 3-\mathrm{S} 2 \uparrow, \mathrm{S} 2-\mathrm{S} 1 \downarrow(\mathrm{S} 2 / \mathrm{S} 3>1 \text { and } \mathrm{S} 1 / \mathrm{S} 2<1)^{\mathrm{a}}$} & \multicolumn{3}{|c|}{$\mathrm{S} 3-\mathrm{S} 2 \downarrow, \mathrm{S} 2-\mathrm{S} 1 \uparrow(\mathrm{S} 2 / \mathrm{S} 3<1 \text { and } \mathrm{S} 1 / \mathrm{S} 2>1)^{\mathrm{a}}$} \\
\hline \multirow{2}{*}{$\begin{array}{l}\text { Name } \\
\text { rno-miR-195 }\end{array}$} & \multicolumn{2}{|c|}{ Fold changes } & \multirow{2}{*}{$\frac{\text { Name }}{\text { rno-miR-let-7b }}$} & \multicolumn{2}{|c|}{ Fold changes } \\
\hline & 13.549629 & 0.9854888 & & 0.99745790 & 1.470588872 \\
\hline rno-miR-34a & 12.426133 & 0.6040662 & rno-miR-466b-1* & 0.99315310 & 1.732802323 \\
\hline rno-miR-347 & 10.659673 & 0.6544392 & rno-miR-107 & 0.95708310 & 1.453658569 \\
\hline rno-miR-503* & 7.3622807 & 0.2163902 & rno-miR-291a-5p & 0.94483460 & 1.724463405 \\
\hline rno-miR-495 & 6.0282288 & 0.3506531 & rno-miR-3572 & 0.93592810 & 1.020299247 \\
\hline rno-miR-10a-3p & 4.0970221 & 0.0661559 & rno-miR-883* & 0.92618030 & 2.217677800 \\
\hline rno-miR-30c- $1 *$ & 3.8809911 & 0.5900630 & rno-miR-466b-2* & 0.92215430 & 1.223710712 \\
\hline rno-miR-24-2* & 3.8646984 & 0.9495285 & rno-miR-375 & 0.91535550 & 1.059154957 \\
\hline rno-miR-339-5p & 3.1913082 & 0.3121446 & rno-miR-466c & 0.89813410 & 1.398870274 \\
\hline rno-miR-379 & 3.1248495 & 0.4766527 & rno-miR-770* & 0.89243770 & 1.651569420 \\
\hline rno-miR-672 & 3.0738620 & 0.9356720 & rno-miR-200c & 0.87946140 & 1.146764503 \\
\hline rno-miR-376-3p & 3.0653762 & 0.3206239 & rno-miR-300-5p & 0.87661250 & 1.733430021 \\
\hline rno-miR-136* & 2.8064011 & 0.7382026 & rno-miR-325-3p & 0.86575560 & 1.913369777 \\
\hline rno-miR-127* & 2.7881470 & 0.8166521 & rno-miR-3573-3p & 0.85555160 & 2.199396790 \\
\hline rno-miR-322 & 2.7181080 & 0.5153748 & rno-miR-210 & 0.85130860 & 1.444849465 \\
\hline rno-miR-409-5p & 2.7004505 & 0.2778741 & rno-miR-30a & 0.83405280 & 4.448185340 \\
\hline rno-miR-16 & 2.4124438 & 0.5187975 & rno-miR-30e* & 0.82078630 & 1.911407722 \\
\hline rno-miR-194* & 2.3146718 & 0.0961872 & rno-miR-433* & 0.78441850 & 1.462433489 \\
\hline rno-miR-15b & 2.2900781 & 0.2570223 & rno-miR-30c & 0.78415490 & 1.641928548 \\
\hline rno-miR-365 & 2.1816797 & 0.2143063 & rno-miR-200a & 0.77613210 & 1.728426011 \\
\hline rno-miR-185 & 2.1641823 & 0.1573393 & rno-miR-344b-2-3p & 0.77200260 & 1.214345429 \\
\hline rno-miR-98 & 2.1485470 & 0.8302507 & rno-miR-3596c & 0.73287290 & 1.961526568 \\
\hline rno-miR-328a & 2.0544097 & 0.0597691 & rno-miR-551b* & 0.70730060 & 4.873483536 \\
\hline rno-miR-448* & 2.0526945 & 0.4748063 & rno-miR-500 & 0.69860000 & 1.352811809 \\
\hline rno-miR-335 & 1.9220501 & 0.6855958 & rno-miR-450a* & 0.69203410 & 3.284467450 \\
\hline rno-miR-466b & 1.7737696 & 0.5701351 & rno-miR-300-3p & 0.67563510 & 1.421903839 \\
\hline rno-miR-200b & 1.7686778 & 0.8490812 & rno-miR-675 & 0.66297150 & 1.881596970 \\
\hline rno-miR-199a-3p & 1.7519083 & 0.3819046 & rno-miR-667 & 0.66158250 & 1.851774707 \\
\hline rno-miR-429 & 1.7345297 & 0.6532936 & rno-miR-101a & 0.63908846 & 1.599289011 \\
\hline rno-miR-206 & 1.6451149 & 0.5619425 & rno-miR-668 & 0.62312700 & 1.546920336 \\
\hline rno-miR-665 & 1.5267099 & 0.2914475 & rno-miR-183* & 0.61654370 & 2.938326520 \\
\hline rno-miR-17-1-3p & 1.4533188 & 0.2164874 & rno-miR-181a & 0.60586140 & 1.027205203 \\
\hline rno-miR-99b* & 1.4381097 & 0.9020220 & rno-miR-22* & 0.59792190 & 1.458050402 \\
\hline rno-miR-30e & 1.4249814 & 0.9009271 & rno-miR-3571 & 0.59185380 & 1.660526533 \\
\hline rno-miR-664-2* & 1.3842126 & 0.0870265 & rno-miR-24-1* & 0.58317060 & 2.889240932 \\
\hline rno-miR-142-3p & 1.3621145 & 0.6892047 & rno-miR-145* & 0.55848840 & 1.061437866 \\
\hline rno-miR-423 & 1.3421092 & 0.7849327 & rno-miR-99b & 0.52918460 & 1.484742511 \\
\hline rno-miR-let-7i & 1.3092522 & 0.4607812 & rno-miR-872* & 0.50684120 & 3.472207096 \\
\hline rno-miR-410 & 1.3015181 & 0.7325175 & rno-miR-30b-3p & 0.50448300 & 1.170676650 \\
\hline rno-miR-490 & 1.2756753 & 0.7856162 & rno-miR-877 & 0.48686730 & 1.339451220 \\
\hline rno-miR-466d & 1.2712970 & 0.9663230 & rno-miR-423* & 0.44084070 & 1.653788675 \\
\hline rno-miR-193 & 1.2541245 & 0.7348141 & rno-miR-541 & 0.42540900 & 1.207167473 \\
\hline rno-miR-22 & 1.1550101 & 0.7615345 & rno-miR-124 & 0.39048060 & 2.030618140 \\
\hline rno-miR-374 & 1.1515834 & 0.6490015 & rno-miR-351 & 0.38371410 & 3.656196612 \\
\hline rno-miR-2985 & 1.1071099 & 0.9055459 & rno-miR-369-3p & 0.37871630 & 2.411181539 \\
\hline rno-miR-301a & 1.0911573 & 0.4289909 & rno-miR-125a-5p & 0.34660480 & 1.113517147 \\
\hline rno-miR-142-5p & 1.0873938 & 0.9302832 & rno-miR-103-1* & 0.31836890 & 1.464945944 \\
\hline rno-miR-205 & 1.0665678 & 0.0960427 & rno-miR-1193-3p & 0.29953480 & 5.522615564 \\
\hline rno-miR-92b & 1.0280013 & 0.3149766 & rno-miR-33 & 0.29346730 & 1.899358020 \\
\hline rno-miR-126 & 1.0129183 & 0.9994663 & rno-miR-341 & 0.19430920 & 1.452073739 \\
\hline rno-miR-let-7e & 1.0102800 & 0.9453700 & rno-miR-542-3p & 0.16812910 & 2.681449923 \\
\hline & & & rno-miR-148b-3p & 0.09409170 & 2.009611745 \\
\hline
\end{tabular}

\footnotetext{
${ }^{\text {a} A r r a n g e d ~ f r o m ~ h i g h ~ t o ~ l o w ~ a c c o r d i n g ~ t o ~ t h e ~ f o l d ~ c h a n g e s ~ b e t w e e n ~} \mathrm{~S} 2 / \mathrm{S} 3$.
} 

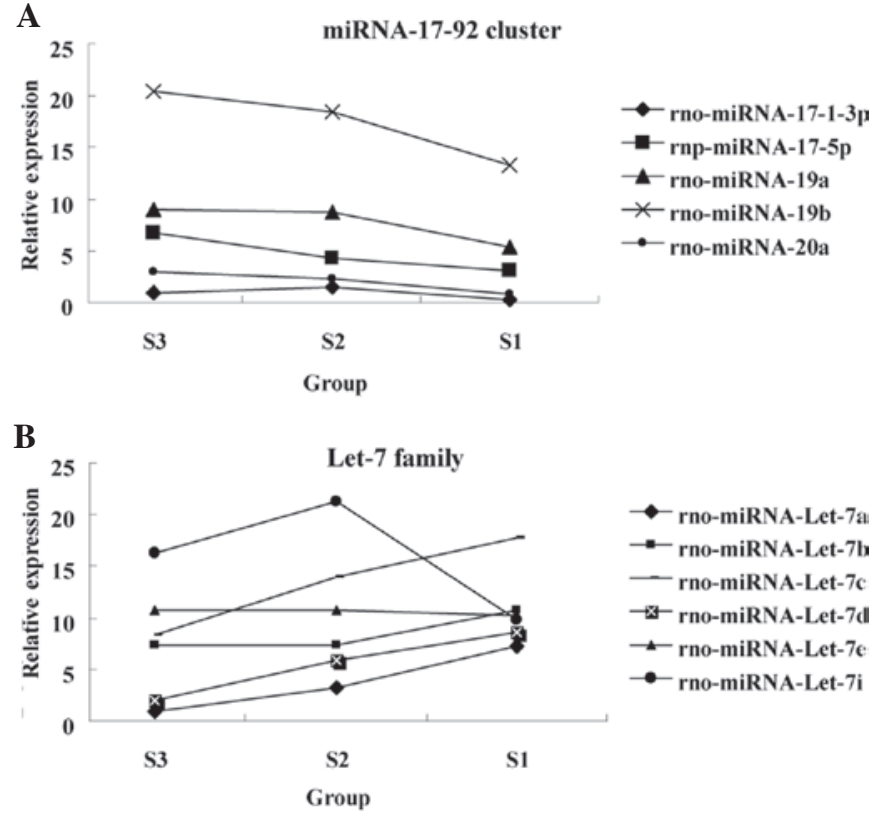

Figure 3. (A) Data show the relative expression trends of the miRNA-17-92 cluster among the 3 groups (S1, S2 and S3). (B) Data show the relative expression trends of the Let- 7 family among the 3 groups according to the microarray results.

A The expression patterns of rno-miRNA-126 and rno-miRNA-126*

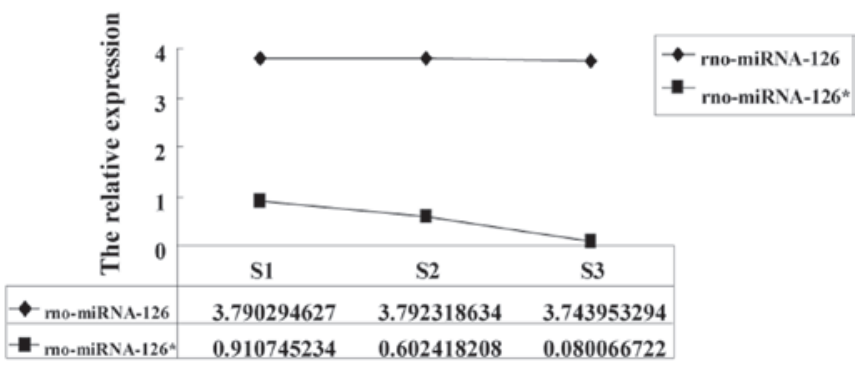

B

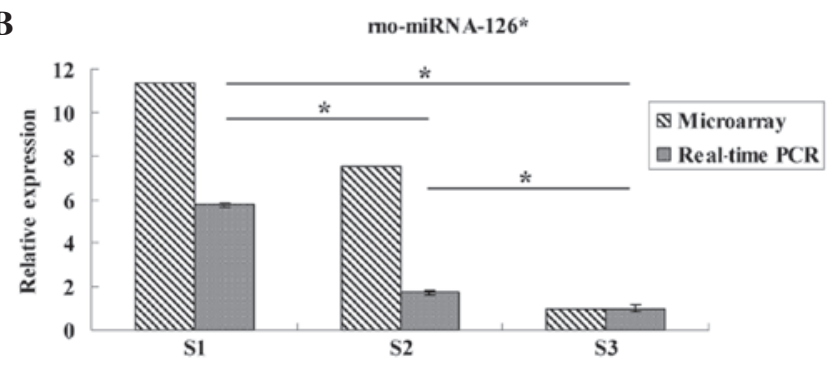

Figure 4. (A) Data show the relative expression trends of the rno-miRNA-126 and rno-miRNA-126* according to the microarray results. (B) Data show the results of the rno-miRNA-126* real-time PCR assay. In real time PCR, data were normalized using U6 as an endogenous control for RNA input. Fold changes for rno-miRNA-126* from the array and real-time qRT-PCR are shown as the mean. Error bars are SE. Statistical significance of the real-time PCR was tested according to the one-way ANOVA ( $\mathrm{P}<0.05)$.

to be highly enriched in mouse embryonic stem cells (15). Additionally, more than one study has reported their significance in the vascular endothelial cells of the embryo $(14,15)$. Therefore, we also prepared line charts to show the expression patterns of rno-miRNA-126* and rno-miRNA-126 in order to further study their possible effects in the lung development of embryos (Fig. 4).

Real-time PCR. Due to the exhibition of marked differential expression between rno-miRNA-126* and rno-miRNA-126 in the microarray, we selected the former for analysis by real-time PCR (Fig. 4). The results revealed that the relative expression of rno-miRNA-126* determined by real-time PCR was consistent with the microarray result, revealing significant differences among the 3 groups $(\mathrm{P}<0.05$; Fig. 4).

\section{Discussion}

In the present study, we used the latest microarray technology to prepare a miRNA expression profile among three time points of fetal lung development, with 202 differentially expressed miRNAs being identified, including four different expression patterns. Among these miRNAs, a number are reported for the first time in the field of lung development, including rno-miRNA-126*, rno-miRNA-186*, rno-miRNA-25, rnomiRNA-195 and rno-miRNA-107 (Table IV).

In addition to these newly identified miRNAs, we also found certain classical ones associated with lung development, for example, the Let-7 family and miRNA-17-92 cluster, and their expression patterns are shown as line charts in Fig. 3. For several years, these two types of miRNAs have been reported and studied repeatedly due to their important roles in lung development and lung cancer. Johnson et al (10) reported that Let-7 is highly expressed in the developing lungs during mouse embryogenesis. Furthermore, they demonstrated that the Let-7 family directly regulates a number of key cell cycle proto-oncogenes, including RAS, CDC25a, CDK6 and cyclin D, and thus may further regulate cell proliferation by promoting the G1 phase into the $\mathrm{S}$ phase. Compared with the high expression in lung development, certain members of this family have been found to be deregulated in specific processes involved in pathological mechanisms, including pulmonary allergy, asthma and lung cancer (11). These findings indicate that the Let-7 family is essential to lung homeostasis and development.

With regard to the miRNA-17-92 cluster, Lu et al (12) firstly reported that its expression is high at the embryo stage and steadily declines during the development into adulthood. The authors further reported that overexpression of the miRNA-17-92 cluster in murine models resulted in abnormalities, in particular, terminal air sacs were lacking and were replaced by undifferentiated and highly proliferative pulmonary epithelium. By contrast, Ventura et al (13) demonstrated that mice deficient in the miRNA-17-92 cluster exhibited an altered phenotype characterized by hypoplasia of the lung. Subsequently, these findings were confirmed by Jevnaker et al (16) and Carraro et al (17), respectively. In this study, we also screened these two important types of miRNA. Their expression patterns are additionally presented as line charts. Moreover, the expression trends are essentially in agreement with the former studies (Fig. 3). The expression of the Let-7 family increased gradually from group S3 (E16) to S1 (E21), while the expression of the miRNA-17-92 cluster manifested a downward trend as the fetal lung grew.

Compared with these intensely investigated miRNAs, certain other miRNAs, including miRNA-126* and miRNA-126, have rarely been discussed in relation to lung 
development. miRNA-126* and miRNA-126 originate from the same domain [both mapping to intron-9 of the epidermal growth factor-like domain 7 gene (Egfl7) (14)]; the common miRNA-126 (known as miRNA-126-3p) was firstly identified in mouse (18) and another less common miRNA-126 was later revealed to be processed from the 5'-half of the same pre-miRNA and was therefore renamed miRNA-126* (also known as miRNA-126-5p). Although introns occupy a large portion of all genomes of eukaryotes and have been generally considered to be sequences that exist only to be removed and destroyed $(19,20)$, the finding of intronic miRNA has indicated that certain excised introns may have particular functions. These include intron-9 in the Egfl7 gene, which has been repeatedly demonstrated to be expressed at high levels in the vasculature associated with tissue proliferation and is abundant in specific organs, including the lungs (14,21-23).

miRNA-126 and miRNA-126* are processed from the same primary miRNA and located in the same intron of Egfl7, a well-known epidermal growth factor domain gene (14). These two miRNAs have been found to be highly enriched in endothelial cells derived from mouse embryonic stem cells (15). Consequently, they are likely to be critical in the regulation of vascular integrity and angiogenesis $(15,24)$. During the past several years, related studies on miRNA-126 and miRNA-126* have mostly been limited to the pathogenesis of cancers. Due to miRNA-126 targeting the vascular endothelial growth factor A (VEGFA), sprouty-related, EVH1 domain-containing protein 1 (Spred-1) and phosphatidylinositol 3-kinase (PI3K), its expression has been found to be decreased in human breast cancer. By contrast, in lung cancer, miRNA-126 has been shown to be upregulated to decrease the growth rate of cell lines in vitro (25), partially through the VEGF/PI3K signaling pathway (26). Moreover, Liu et al (25) focused on the miRNA-126 interaction with VEGF in lung cancer cells and three other cancer cell lines infected with LV-miRNA-126, and revealed that miRNA126 efficiently reduced the expression of VEGF and inhibited cell proliferation as a potential tumor suppressor. Moreover, two more studies demonstrated that the role of miRNA-126 as a tumor suppressor in lung cancers may be due to its regulation of chicken tumor virus no. 10 regulator of kinase (Crk), which has been described in lung cancer and associated with increased tumor invasiveness $(27,28)$. These studies suggest that miRNA-126 and miRNA-126* have various roles in developmental angiogenesis as well as in carcinogenesis (29).

Compared with that of miRNA-126, the role of miRNA-126* is less understood, with the exception of its joint function with miRNA-126 in VEGF and angiogenesis. Musiyenko et al (30) reported that the natural absence of Egfl7 leads to the absence of its intronic mRNA (miRNA-126*), which indirectly promotes the invasiveness of $\mathrm{LNCaP}$ prostate cancer cells by allowing the expression of protein. This is one of the few studies concerning the function of miRNA-126*. Until several years ago, it was assumed that one strand of the RNA duplex preferentially binds to the silencing complex during the processing of miRNA, whereas the other strand, i.e., miRNA* is degraded (31), representing a functionally irrelevant carrier strand. However, subsequently, miRNA* species have been detected in increasing numbers with large-scale small RNA sequencing efforts. In the case of miRNA-126/miRNA-126*, they have been detected with high expression levels in the same tissue (32). In addition, the two strands of a miRNA pair are able to functionally suppress the expression of their target genes $(33,34)$. Therefore, compared with common miRNA-126, miRNA-126* may also have its own special functions (29).

Since miRNA-126 and miRNA-126* originate from the Egfl7 gene and share a common mRNA, in previous reports, their expression appeared always to be generally in parallel $(15,23)$. Nevertheless, there are currently a few studies which report that miRNA-126 expression is regulated independently of the EGFL7 protein (35), suggesting that independent promoters may exist which regulate the expression of miRNA-126 and miRNA-126*, further indicating that they may each have respective roles in different signaling pathways and physiological mechanisms. In the present study, following the microarray screening, we found that miRNA-126 did not exhibit the same differential expression as miRNA-126* in the three groups (Fig. 4), verifying the above hypothesis.

The results of a subsequent real-time PCR assay demonstrated that miRNA-126* has significant differences in expression among the three time points (group $\mathrm{S} 3 \rightarrow \mathrm{S} 2 \rightarrow \mathrm{S} 1$ ) (Fig. 4). This is the first time that the differential expression of miRNA-126* has been reported in fetal lung development and, according to these results, we suggest that miRNA-126* is important in the process of fetal lung development, since its expression increases gradually as the lung develops.

As previously stated, most of the studies on these two miRNAs have been conducted in cancers. However, cells at an early stage of development are known to share several characteristics with carcinoma cells, including high and rapid proliferation. The higher tissue levels of miRNA-126/126* in carcinoma cells are closely associated with their role in angiogenesis. Therefore, in the embryo, the two miRNAs may also promote lung development through the same mechanism since these two processes share the same characteristics. This hypothesis may also help to explain the role of miRNA-126* in fetal lung development in the rat embryo. Furthermore, we consider that these findings are likely to lay a certain physiological foundation for studies concerning neonatal lung developmental diseases, including RDS (respiratory distress syndrome) and BPD (bronchopulmonary dysplasia). Therefore, future studies are necessary.

\section{Acknowledgements}

The authors would like to thank Dr Shi for assistance in the revision of this manuscript. This study was funded by the Project Foundation of Jiangsu Province Health Department (no. H200642).

\section{References}

1. Croce CM and Calin GA: miRNAs, cancer, and stem cell division. Cell 122: 6-7, 2005.

2. Iorio MV and Croce CM: MicroRNAs in cancer: small molecules with a huge impact. J Clin Oncol 27: 5848-5856, 2009.

3. Lee RC, Feinbaum RL and Ambros V: The C. elegans heterochronic gene lin-4 encodes small RNAs with antisense complementarity to lin-14. Cell 75: 843-854, 1993.

4. Grimson A, Farh KK, Johnston WK, Garrett-Engele P, Lim LP and Bartel DP: MicroRNA targeting specificity in mammals: determinants beyond seed pairing. Mol Cell 27: 91-105, 2007. 
5. Mertens-Talcott SU, Chintharlapalli S, Li X and Safe S: The oncogenic microRNA-27a targets genes that regulate specificity protein transcription factors and the G2-M checkpoint in MDA-MB-231 breast cancer cells. Cancer Res 67: 11001-11011, 2007.

6. Fabbri M, Garzon R, Cimmino A, et al: MicroRNA-29 family reverts aberrant methylation in lung cancer by targeting DNA methyltransferases 3A and 3B. Proc Natl Acad Sci USA 104 15805-15810, 2007

7. Stefani G and Slack FJ: Small non-coding RNAs in animal development. Nat Rev Mol Cell Biol 9: 219-230, 2008.

8. Williams AE, Moschos SA, Perry MM, Barnes PJ and Lindsay MA: Maternally imprinted microRNAs are differentially expressed during mouse and human lung development Dev Dyn 236: 572-580, 2007.

9. Williams AE, Perry MM, Moschos SA and Lindsay MA: microRNA expression in the aging mouse lung. BMC Genomics 8: 172, 2007.

10. Johnson CD, Esquela-Kerscher A, Stefani G, et al: The let-7 microRNA represses cell proliferation pathways in human cells. Cancer Res 67: 7713-7722, 2007.

11. Tomankova T, Petrek M and Kriegova E: Involvement of microRNAs in physiological and pathological processes in the lung. Respir Res 11: 159, 2010.

12. Lu Y, Thomson JM, Wong HY, Hammond SM and Hogan BL: Transgenic overexpression of the microRNA miR-17-92 cluster promotes proliferation and inhibits differentiation of lung epithelial progenitor cells. Dev Biol 310: 442-453, 2007.

13. Ventura A, Young AG, Winslow MM, et al: Targeted deletion reveals essential and overlapping functions of the miR-17 through 92 family of miRNA clusters. Cell 132: 875-886, 2008.

14. Parker LH, Schmidt M,Jin SW, et al: The endothelial-cell-derived secreted factor Egfl7 regulates vascular tube formation. Nature 428: 754-758, 2004

15. Fish JE, Santoro MM, Morton SU, Yu S, Yeh RF, Wythe JD, Ivey KN, Bruneau BG, Stainier DY and Srivastava D: miR-126 regulates angiogenic signaling and vascular integrity. Dev Cell 15: 272-284, 2008.

16. Jevnaker AM, Khuu C, Kjøle E, Bryne M and Osmundsen $\mathrm{H}$ Expression of members of the miRNA17-92 cluster during development and in carcinogenesis. J Cell Physiol 226: 2257-2266, 2011.

17. Carraro G, El-Hashash A, Guidolin D, et al: miR-17 family of microRNAs controls FGF10-mediated embryonic lung epithelial branching morphogenesis through MAPK14 and STAT3 regulation of E-Cadherin distribution. Dev Biol 333: 238-250, 2009.

18. Lagos-Quintana M, Rauhut R, Yalcin A, Meyer J, Lendeckel W and Tuschl T: Identification of tissue specific microRNAs from mouse. Curr Biol 12: 735-739, 2002

19. Naora $\mathrm{H}$ and Deacon NJ: Relationship between the total size of exons and introns in protein-coding genes of higher eukaryotes. Proc Natl Acad Sci USA 79: 6196-6200, 1982.

20. Clement JQ, Qian L, Kaplinsky N and Wilkinson MF: The stability and fate of a spliced intron from vertebrate cells. RNA 5 : 206-220, 1999
21. Soncin F, Mattot V, Lionneton F, Spruyt N, Lepretre F, Begue A and Stehelin D: VE-statin, an endothelial repressor of smooth muscle cell migration. EMBO J 22: 5700-5711, 2003.

22. Fitch MJ, Campagnolo L, Kuhnert F and Stuhlmann H: EGFL7, a novel epidermal growth factordomain gene expressed in endothelial cells. Dev Dyn 230: 316-324, 2004.

23. Campagnolo L, Leahy A, Chitnis S, Koschnick S, FitchxMJ, Fallon JT, Loskutoff D, Taubman MB and Stuhlmann H: EGFL7 is a chemoattractant for endothelial cells and is upregulated in angiogenesis and arterial injury. Am J Pathol 167: 275-284, 2005.

24. Wang S, Aurora AB, Johnson BA, Qi X, McAnally J, Hill JA, Richardson JA, Bassel-Duby R and Olson EN: The endothelialspecific microRNA miR-126 governs vascular integrity and angiogenesis. Dev Cell 15: 261-271, 2008.

25. Liu B, Peng XC, Zheng XL, Wang J and Qin YW: MiR-126 restoration downregulate VEGF and inhibit the growth of lung cancer cell lines in vitro and in vivo. Lung Cancer 66: 169-175, 2009.

26. Zhu N, Zhang D, Xie H, et al: Endothelial-specific intron-derived miR-126 is downregulated in human breast cancer and targets both VEGFA and PIK3R2. Mol Cell Biochem 351: 157-164, 2011.

27. Crawford M, Brawner E, Batte K, Yu L, Hunter MG, Otterson GA, Nuovo G, Marsh CB and Nana-Sinkam SP: MicroRNA-126 inhibits invasion in non-small cell lung carcinoma cell lines. Biochem Biophys Res Commun 373: 607-612, 2008.

28. Yang Y, Li X, Yang Q, Wang X, Zhou Y, Jiang T, Ma Q and Wang YJ: The role of microRNA in human lung squamous cell carcinoma. Cancer Genet Cytogenet 200: 127-133, 2010

29. Meister J and Schmidt MH: miR-126 and miR-126*: new players in cancer. Sci World J 10: 2090-2100, 2010.

30. Musiyenko A, Bitko V and Barik S: Ectopic expression of miR-126*, an intronic product of the vascular endothelial EGF-like 7 gene, regulates prostein translation and invasiveness of prostate cancer LNCaP cells. J Mol Med (Berlin) 86: 313-322, 2008.

31. Bartel DP: MicroRNAs: genomics, biogenesis, mechanism, and function. Cell 116: 281-297, 2004.

32. Saito Y, Friedman JM, Chihara Y, Egger G, Chuang JC and Liang G: Epigenetic therapy upregulates the tumor suppressor microRNA-126 and its host gene EGFL7 in human cancer cells. Biochem Biophys Res Commun 379: 726-731, 2009.

33. Ro S, Park C, Young D, Sanders KM and Yan W: Tissue-dependent paired expression of miRNAs. Nucleic Acids Res 35: 5944-5953, 2007.

34. Okamura K, Phillips MD, Tyler DM, Duan H, Chou YT and Lai EC: The regulatory activity of microRNA* species has substantial influence on microRNA and 3' UTR evolution. Nat Struct Mol Biol 15: 354-363, 2008.

35. Li X, Shen Y, Ichikawa H, Antes T and Goldberg GS: Regulation of miRNA expression by Src and contact normalization: effects on nonanchored cell growth and migration. Oncogene 28: 4272-4283, 2009. 